\title{
Nefrolithiasis pada red eared slider (Trachemys scripta elegans)
}

\author{
Devi Paramitha ${ }^{1}$, Intan Citraningputri ${ }^{2}$, Deni Noviana ${ }^{3}$, Mokhamad Fakhrul Ulum $^{3}{ }^{*}$ \\ ${ }^{1}$ Program Magister Ilmu Biomedis Hewan, Sekolah Pascasarjana, Institut Pertanian Bogor, Jawa Barat \\ ${ }^{2}$ Program Magister Primatologi, Sekolah Pascasarjana, Institut Pertanian Bogor, Jawa Barat \\ ${ }^{3}$ Departemen Klinik, Reproduksi, dan Patologi, Fakultas Kedokteran Hewan, Institut Pertanian Bogor, Jawa Barat
}

\begin{abstract}
ABSTRAK: Kasus nefrolithiasis ini ditemukan pada seekor red eared slider (RES) atau di Indonesia dikenal dengan nama kura-kura Brazil, secara tidak disengaja ketika hewan tersebut diperiksa secara radiografi untuk melihat morfologi normalnya. Kura-kura telah dipelihara selama satu tahun oleh pemilik tanpa ada keluhan apapun. Kura-kura tersebut dipelihara di dalam kolam bersama dengan ikan, pakan yang diberikan pemilik adalah ikan kecil dan sayur. Riwayat kura-kura sebelum dipelihara pemilik tidak diketahui. Radiografi dilakukan melalui 3 standar pandang, yaitu dorsoventral, laterolateral dan craniocaudal. Hasil radiografi dari ketiga standar pandang tersebut menunjukkan adanya massa radiopaque di bagian kanan dan kiri abdomen kura-kura. Pemeriksaan ultrasonografi (USG) dilakukan sebagai diagnosa penunjang. Hasil yang didapat dari pemeriksaan USG ini adalah ditemukan massa hiperekhoik pada ginjal.
\end{abstract}

Kata kunci:

nefrolithiasis, red eared slider (RES), radiografi, ultrasonografi

\section{- PENDAHULUAN}

Nefrolithiasis, atau penyakit batu ginjal adalah kondisi dimana terbentuknya kalkuli (batuan) dalam pelvis dan lumen tubular ginjal. Batuan yang terbentuk dari kristal yang mengendap dari urin. Terbentuknya batu dapat terjadi ketika konsentrasi urin yang mengandung substansi pembentuk kristal tinggi dan/atau substansi yang menghambat pembentukan batu ginjal rendah (Uribarri et al. 1989). Nefrolithiasis merupakan penyakit yang kejadiannya cukup sering pada manusia maupun hewan kecil (Hall 2009), namun jarang sekali ditemukan pada reptil seperti kura-kura.

\section{- KASUS}

Seekor kura-kura RES dibawa ke bagian Bedah dan Radiologi, Fakultas Kedokteran Hewan, Institut Pertanian Bogor untuk dilakukan pengambilan gambar radiografi (Gambar 1). Gambaran radiografi dilakukan melalui 3 standar pandang, yaitu dorso ventral, latero lateral dan cranio caudal. Pemeriksaan ultrasonografi (USG) dilakukan dengan menempelkan transduser pada kulit tubuh dekat kaki belakang kura-kura yang tidak tertutup karapas. Gel utrasonografi diberikan pada daerah pencitraan sebelum tranduser ditempelkan untuk menghasilkan citra yang baik. Interpretasi radiografi dilakukan dengan membandingkan semua radiograf dari setiap standar pandang, dan interpretasi USG dilakukan secara real-time.

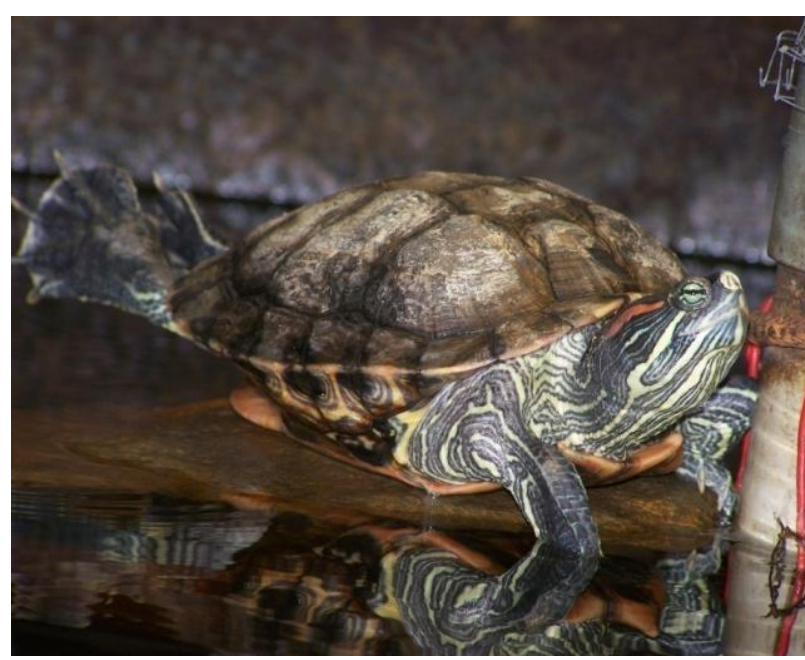

Gambar 1 Kura-kura red eared slider (RES) yang mengalami kasus nefrolithiasis bilateral.

\section{- HASIL DAN PEMBAHASAN}

Gambar 2 menunjukkan hasil pencitraan radiografi. Hasil menunjukkan bahwa pada setiap sudut pandang yang diambil, ditemukan adanya massa radiopaque yang bilateral dan berada di bagian abdomen kura-kura. Diagnosa penunjang ultrasonografi kemudian dilakukan guna mengkonfirmasi massa radiopaque tersebut.

Diterima: 07-04-2018 | Direvisi: 20-05-2018 | Disetujui: 10-06-2018 (c) 2018 CC-BY-SA. Ini adalah artikel Open Access yang didistribusikan berdasarkan ketentuan dari Creative Commons Attribution ShareAlike 4.0 International License (https://creativecommons.org/licenses/by-sa/4.0/). 

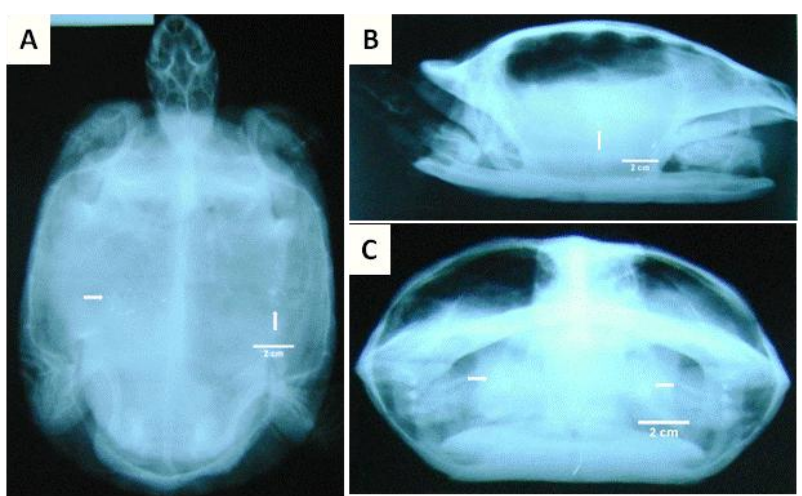

Gambar 2 Kura-kura Red eared slider (RES) yang mengalami kasus nefrolithiasis bilateral. Tanda panah berwarna putih menunjukkan letak urolith. A, sudut pandang dorsoventral, B, sudut pandang laterolateral, $\mathrm{C}$, sudut pandang craniocaudal.

Gambar 3 menunjukkan hasil pencitraan ultrasonografi. Sonogram menunjukkan bahwa ginjal merupakan struktur hipoekhoik berbentuk oval yang pada bagian pyelumnya, yaitu di bagian tengah terdapat massa hiperekhoik yang merupakan batu ginjal.
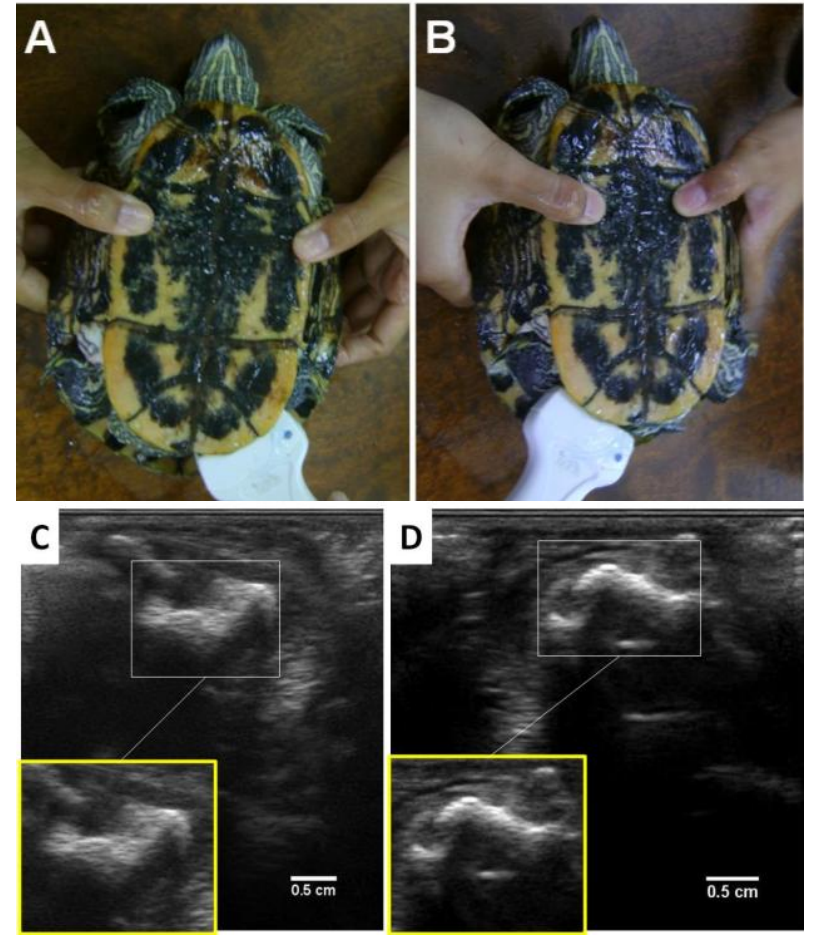

Gambar 2 Ultrasonografi dan sonogram ginjal kura-kura. Teknik pencitraan ginjal kiri (A) dan ginjal kanan (B). Sonogram tampak mas hiperekoik di bagian tengah (pyelum) organ ginjal, masa terlihat jelas pada kedua ginjal, yaitu ginjal kiri (C), dan ginjal kanan (D).

Ginjal kura-kura sepasang, lobular dan merupakan struktur elips berwarna merah yang terletak di daerah retroperitoneal (di antara peritoneum dan karapas), melekat pada permukaan ventral bagian dalam karapas dan kaudal dari acetabula pelvis (Girling 2003). Ginjal kura-kura tidak memiliki bagian korteks dan medula yang jelas, ginjalnya terdiri dari kapsula, tubulus proksimalis yang terkait dengan transport air dan sintesa protein, segmen intermediet yang fungsinya belum diketahui, tubulus distalis convoluted yang bertanggung jawab terhadap reabsorpsi cairan dan tubulus pengumpul. Tidak terdapat lengkung Henle seperti pada ginjal mamalia. Ginjal berfungsi dalam pembuangan limbah nitrogen dan mempertahankan keseimbangan cairan dan elektrolit (Wyneken 2001).

Kalkuli pada saluran urinari, pada sebagian besar kasus yang ditemukan biasanya disebabkan oleh kondisi lingkungan, terutama kekurangan air, dan pakan yang tidak cocok atau diet protein yang berlebihan. Reptil dapat defekasi di dalam akuarium/kolam dan kura-kura makan di dalam air. Kebiasaan ini dapat menimbulkan polusi dan menyebabkan terjadinya penyakit. Pencegahan untuk hal tersebut, air harus dilengkapi dengan sistem filtrasi yang baik, atau kura-kura diberi tempat pakan yang terpisah dan dapat dibersihkan setelah kura-kura selesai makan (Girling 2003).

Reptil, seperti halnya burung, dapat terkena penyakit ginjal karena produk buangan dari metabolism proteinnya didominasi oleh asam urat tak larut. Jika reptil tidak dijaga kecukupan hidrasinya, hal ini dapat menyebabkan turunnya eksresi asam urat melalui ginjal dan menyebabkan asam urat terdeposisi di dalam tubuh yang disebut sebagai visceral gout. Jika telah terdeposisi, maka asam urat akan membentuk lapisan mineral pada pembuluh darah, ginjal, jantung dan organ lainnya yang menimbulkan hipertensi dan kerusakan organ lainnya (Girling 2003). Kramer dan Curhan (2002), menyatakan dalam publikasinya bahwa kejadian gout berkaitan dengan nefrolithiasis.

\section{- SIMPULAN}

Nefrolithiasis dapat terjadi pada kura-kura akibat kondisi lingkungan, terutama kekurangan air, pakan yang tidak cocok atau diet protein yang berlebihan. Selain itu, air kolam tempat dipeliharanya kura-kura juga dapat menyebabkan terjadinya berbagai penyakit termasuk nefrolithiasis.

\section{- INFORMASI PENULIS}

Penulis untuk Korespondensi

*MFU: ulum@ipb.ac.id

Departemen Klinik Reproduksi dan Patologi, Fakultas Kedokteran Hewan, Institut Pertanian Bogor, Jalan Agatis Kampus IPB Dramaga Bogor Jawa Barat 16680.

\section{- PUSTAKA ACUAN}

Girling S. 2003. Veterinary Nursing of Exotic Pets. Oxford : Blackwell Publishing.

Hall PM. 2009. Nephrolithiasis : Treatment, causes and prevention. Cleveland Clinic Journal of Medicine. 76(10): 583-591.

Kramer HM, Curhan G. 2002. The association between gout and nephrolithiasis: the National Health and Nutrition Examination Survey III, 1988-1994. Am J Kidney Dis. 40(1):37-42.

Uribarri J, Oh MS, Carroll HJ. 1989. The first kidney stone. Ann Intern Med. 111(12):1006-9.

Wyneken J. 2001. The Anatomy of Sea Turtles. NOAA Technical Memorandum. 470: 152-165. 